\title{
Pilot Studies on Membranes and some Transport Mechanisms in Friedreich's Ataxia
}

\author{
A. FILLA, R.F.BUTTER WORTH AND A.BARBEAU
}

\begin{abstract}
SUMMARY: The observed anomalies in high density lipoproteins in Friedreich's ataxia led us to investigate the state of cellular membranes in this illness. As a preliminary screening program, we studied the shape of erythrocytes; the phospholipid content of platelets and the transport properties of these membranes as indirect$1 y$ reflected in the absorption of Vit $E$ and the renal handling of orally injected taurine. All these investigations were normal, except for a tendency towards more echinocytes in Friedreich's ataxia and the significant increase in taurine urinary excretion after an oral load. We concluded that the possible membrane abnormalities are not major and will have to be searched for with more subtle and specific tests.
\end{abstract}

RÉSUMÉ: Les anomalies observées dans les lipoprotéines à haute densité de l'ataxie de Friedreich nous ont conduit à étudier l'état des membranes cellulaires dans cette maladie. Comme étape préliminaire nous avons investigué la forme des érythrocytes, le contenu en phospholipides des plaquettes et les propriétés de transport indirectement reflétées dans l'absorption de la vitamine $E$ et la disposition rénale d'une dose orale de taurine. Toutes ces études ont donné des résultats normaux, sauf pour une tendance à une plus grande formation d'échinocytes par les ataxiques et une augmentation significative de l'excrétion urinaire de la taurine après une surcharge orale. Il faut donc conclure que les anomalies membranaires postulées ne sont certainement pas majeures, mais il est possible qu'elles soient mises en évidence par des tests plus subtils et plus spécifiques.

From The Department of Neurobiology, Clinical Research Institute of Montreal.

Reprint requests for the complete supplement on Friedreich's Ataxia (Phase Two, Part Two) to:

Dr. André Barbeau, Clinical Research Institute of Montreal, 110 Pine Avenue West, Montreal, Quebec, Canada, H2W IR7

\section{INTRODUCTION}

One of the important findings of our Phase Two studies has been the high density lipoprotein (HDL) fraction (Huang et al., 1978). Because the cholesterol and phospholipid content of membranes is dependent on the surrounding milieu, and can be exchanged with the lipoproteins of the milieu, the eventual significance of the HDL defect could be a modification of membrane structure or fluidity in Friedreich's ataxia.

Such alterations could be evident through modifications in the shape or composition of the membranes of easily accessible cells, such as the erythrocyte or the platelet. Similarly, if membranes are abnormal, impaired intestinal absorption or specific renal handling could be expected in some cases. Since such indications can be obtained through fairly straightforward tests, these were undertaken as a preliminary exploration of possible membrane involvement in Friedreich's ataxia before more specific investigations, such as electron spin resonance, nuclear magnetic resonance, and lectin agglutination could be carried out. The present paper reports the results of such preliminary studies.

\section{SUBJECTS AND METHODS}

a) Erythrocyte shape modifications

Venous blood (5 $\mathrm{ml}$ with heparin and $10 \mathrm{ml}$ without anti-coagulant) was collected in the fasting state from 10 ataxic patients and 6 age-matched healthy control subjects. The heparinized blood was immediately centrifuged at 2,000 rpm to separate red blood cells (RBC) from plasma. Erythrocytes were suspended in tissue culture medium 199 (Gibco-Grand Island, N.Y.) with 10 percent autologous serum (Mars et al., 1969), and diluted 1/200. $10 \mathrm{ml}$ of the suspension in $25 \mathrm{ml}$ Erlenmeyer Flasks were incubated in an atmosphere of 95 percent $0_{2} / 5$ percent $\mathrm{CO}_{2}$ at $37^{\circ} \mathrm{C}$, for four hours in a metabolic water bath shaker (New Brunswick Scientific Co. Inc., New Brunswick, New Jersey). Every hour specimens were examined on disposable vinyl plastic microslides (Thomas Scientific Apparatus, Cat. No. 6686-V15) by light microscopy at magnification $400 \mathrm{X}$. One thousand cells were counted for each slide and the percentage of deformed cells calculated. In each experiment at least one control was run together with one or more patients.

\section{b) Platelet phospholipid content}

Platelet phospholipid content was determined by thin layer chromatography according to the detailed method of Marcus et al. (1972) in 65 subjects: 5 young controls; 6 controls 40-70 years of age; 10 parkinsonian patients without levodopa, and 10 with; 5 Huntington's chorea patients; 8 with chronic multiple sclerosis, and 10 with typical Friedreich's ataxia.

\section{c) Vitamin $E$ in serum}

Serum Vitamin E levels were determined in 10 normal control subjects, 30 ataxic patients (15 with typical Friedreich's ataxia and 15 with other forms of hereditary ataxia) and 16 neurological disease controls, agematched. Vitamin E assay was performed spectrophometrically in triplicate, as described by Martinek (1964) with modifications according to Tsen (1961).

\section{d) Renal handling of a taurine load}

The renal handling of taurine was estimated in 5 patients affected with typical Friedreich's ataxia (from 
different sibships) and 5 age-matched normal controls. Specimens of urine were collected for two hours before, and 24 hours after the oral absorption of a $250 \mathrm{mg}$ taurine load (ICN Company). Two hour samples were collected until 17:00 hrs and the last sample was made up of the overnight (17:00-07:00) hrs) collection. Patients and controls received a standard diet during the 3 days preceding the experiments and during the collection period. Taurine was measured by the method of Anfano et al. (1978).

\section{RESULTS}

\section{a) Erythrocytes}

As can be seen in Table 1, the percentage of distorted erythrocytes (echinocytes) shows no statistical difference between the control subjects and the ataxic patients. However, it is noteworthy that at each time period the mean level for Friedreich's ataxia is always approximately $20 \%$ higher than the mean for control subjects, even if the difference is not significant with the relatively small number of individuals tested.

\section{b) Platelet phospholipids}

The study of the various phospholipids in platelets, as seen in Table 2, did not reveal any significant difference between ataxic subjects and their age-matched controls. However, the combined levels phosphatidyl-serine and phosphatidyl-inositol are lower than in age-matched controls (approaching significance). It is also interesting to note that in parkinsonian patients treated with levodopa most phospholipid absolute values are lower than without this treatment, and even lower than in age-matched controls.

\section{c) Vitamin $E$}

Similar negative results are observed in the study of vitamin $E$ in the serum. As seen in Table 3 there was no significant difference between levels in ataxic patients and normal or disease controls, although the levels in Friedreich's ataxia tended to be lower than the other groups. A single Friedreich patient had a value of 0.28 , which is pathologically low, but not within the range of BassenKornzweig's disease.

\section{e) Oral taurine load}

The overall pattern of urinary excretion of taurine after an oral load of $250 \mathrm{mg}$ of taurine (a level just above the normal dietary ingestion) is essentially similar to that seen in age and sex-matched controls (Figure 1). However, the ataxic subjects uniformly excreted twice as much of the load as the controls. This was true in each matched pair and is highly significant statistically.

\section{DISCUSSION}

Many diseases are manifested by abnormalities in membranes which are sometimes reflected in the shape of erythrocytes. Thus, increased cholesterol content in erythrocyte membranes associated with $\beta$-lipoprotein abnormalities have been detected in "spur cell" anemia and in acquired hypo- $\beta$-lipoproteinemia in undernourished infants (McBride et al.,

TABLE 1

\% Erythrocyte Distortion

\begin{tabular}{l|ccccc}
\hline Controls (n=6) & \multicolumn{5}{|c}{ Hours } \\
& $\mathbf{1}$ & $\mathbf{2}$ & $\mathbf{3}$ & $\mathbf{4}$ & $\mathbf{5}$ \\
\hline Mean & 3.8 & 4.59 & 4.93 & 4.27 & 4.87 \\
S.D. & 0.91 & 1.88 & 6.0 & 2.16 & 4.65 \\
S.E. & 0.41 & 0.84 & 2.68 & 0.97 & 2.08 \\
\hline Patients (n=10) & & & & & \\
\hline & & & & & \\
Mean & 5.24 & 6.5 & 6.3 & 6.22 & 6.02 \\
S.D. & 4.23 & 4.15 & 4.42 & 4.20 & 3.92 \\
S.E. & 1.89 & 1.38 & 1.47 & 1.40 & 1.31 \\
$\mathbf{t}=$ & 0.74 & 1.18 & 0.45 & 1.14 & 0.47 \\
\hline
\end{tabular}

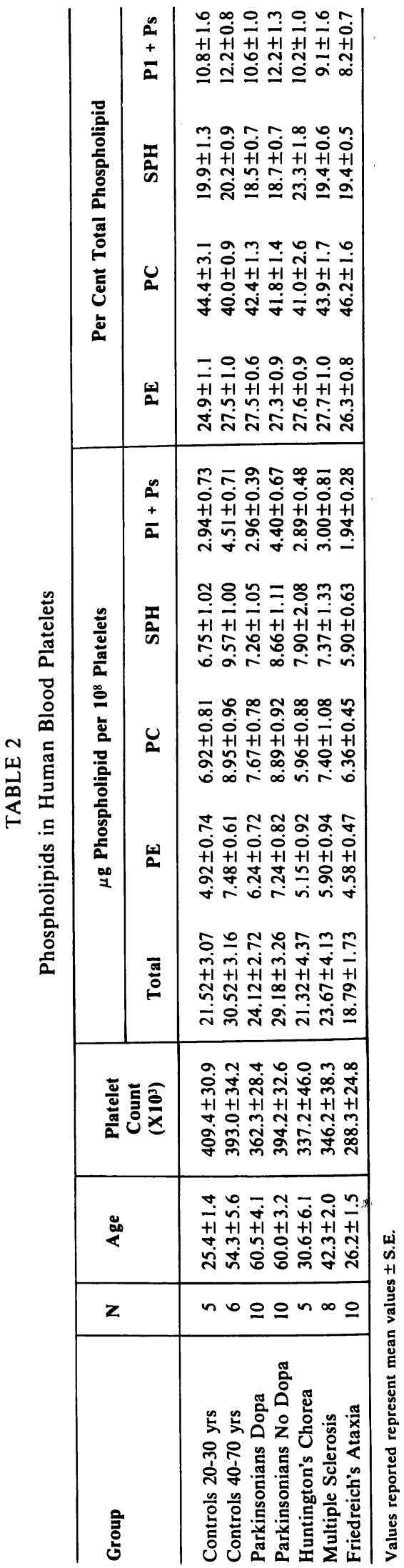


1970). Absence of LDL and changes in HDL have been described in plasma of patients with the Bassen-Kornzweig syndrome. In this disease, one finds low levels of cholesterol, phospholipids, and triglycerides in plasma with decreased concentrations of linoleic acid in all fractions and a reduced ratio of phosphatidyl-choline/sphingomyelin. These abnormalities are reflected in red cell membranes which contain less phosphatidylcholine and more sphingomyelin, but almost the same total amounts of phospholipids as normal cells (Fredrickson et al., 1972). Similar, but less evident lipid changes have been found in familial hypobetalipoproteinemia.

Red cell membrane changes from patients with muscular dystrophy have also been shown to differ from normal with respect to fatty acids and phospholipid composition (Kunze et al., 1973). More recently, decreased palmitoleic acid and triglyceride levels have been detected in erythrocytes from Duchenne muscular dystrophy patients (Howland et al., 1977). Many forms of muscular dystrophy (Matheson et al., 1974) and myotonic dystrophy (Roses et al., 1974) can be accompanied by deformations in the shape of erythrocytes. However, the mechanism of "spurring" still remains unclear. Some distortion is attributed to changes in cation distribution consequent to modifications in membrane lipids (Matheson et al., 1974). Abnormal kinetics in the exchange of cholesterol has been implicated in the mechanism of "spurring" in abetalipoproteinemia.

Modifications in HDL lipoproteins in Friedreich's ataxia could lead to disturbed cholesterol exchange with membranes. However, the degree of echinocyte formation observed in this disease, although always more

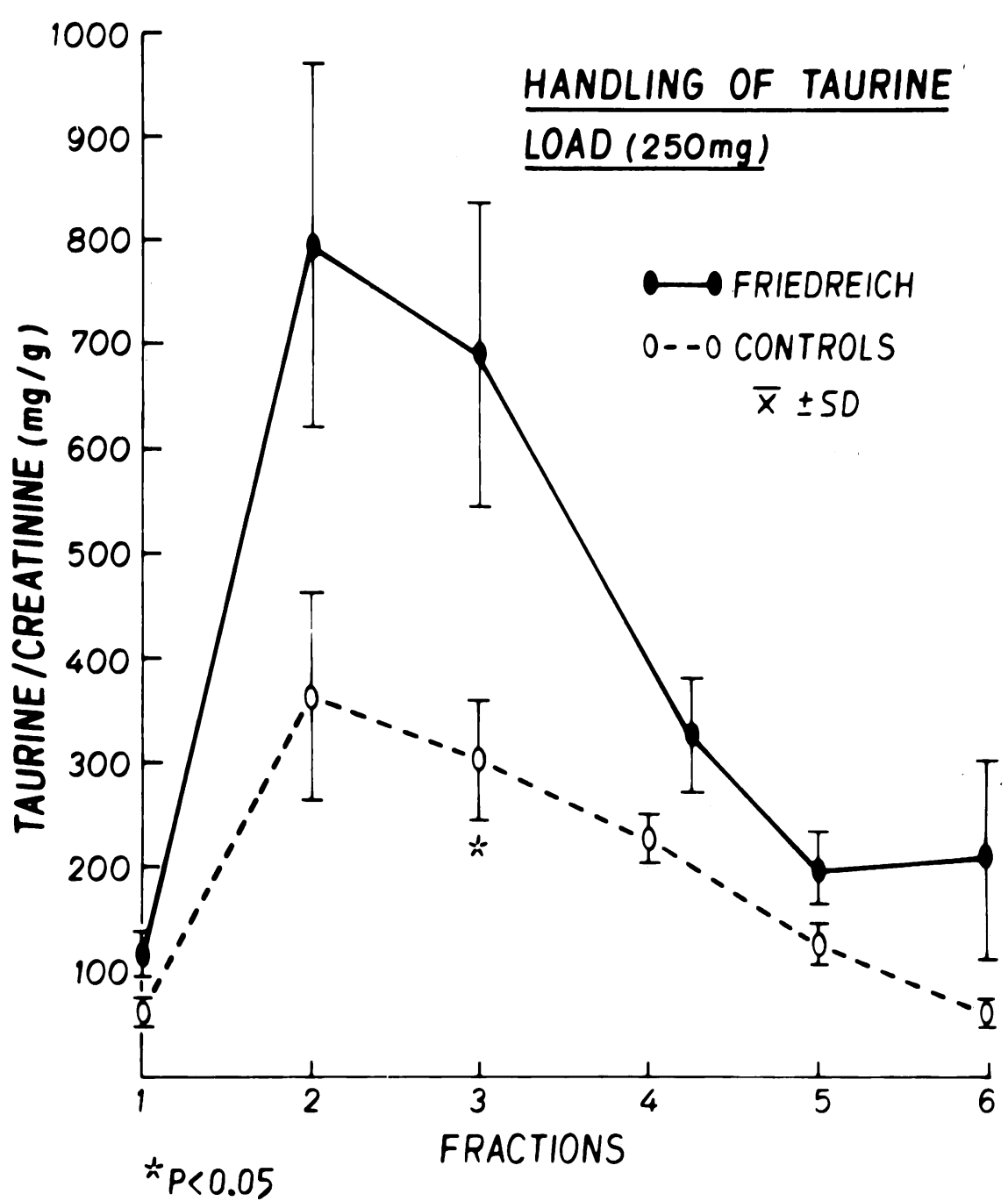

Figure 1-Urinary excretion of taurine after an oral load of $250 \mathrm{mg}$ of taurine as determined by timed urinary collections in Friedreich's ataxia and age-matched controls. important than in controls, was not significant in our studies. Similarly, we could not demonstrate (Table 2) significant changes in the phospholipid pattern in platelets in patients with Friedreich's ataxia, Parkinson's disease, Huntington's chorea, and
TABLE 3

Serum Vitamin E

\begin{tabular}{l|cccc}
\hline & N & $\begin{array}{c}\text { Mean } \\
(\mathbf{m g \%})\end{array}$ & S.D. & S.E. \\
\hline 1. Controls & 10 & 0.69 & 0.11 & 0.04 \\
2. Ataxic Patients & 30 & 0.65 & 0.20 & 0.04 \\
2a. Friedreich & 15 & 0.61 & 0.18 & 0.04 \\
3. Disease Controls & 16 & 0.72 & 0.17 & 0.04 \\
\hline
\end{tabular}

multiple sclerosis, all diseases with postulated fatty acid lipid changes in the plasma and occasionally in membranes (Karlsson et al., 1971).

Vitamin $E$ has been extensively investigated in recent years, but its physiological function and mechanisms of action are still unclear. However, there exists a fat soluble vitamin deficiency syndrome resembling Friedreich's ataxia manifested clinically by progressive ataxia, areflexia, impaired position sense, and absent vibration sense after small bowel resection (Bertoni et al., 1978). Vitamin E deficiency has been recently associated with progressive ataxia, impaired position and vibration sense and areflexia in a patient with cystic 
fibrosis (Jackson, 1977, quoted by Bertoni et al., 1978). Moreover, the lowest plasma concentrations of vitamin $E$ in humans have been reported in abetalipoproteinemia (Fredrickson et al., 1972). It was thus of interest in Friedreich's ataxia when Takahashi and collaborators (1977) demonstrated that vitamin $\mathrm{E}$ is mostly transported by the HDL fraction of serum. Our own results (Table 3 ) fail to demonstrate a significant change in ataxics taken as a group, although the levels of vitamin E in Friedreich's ataxia were clearly, and almost significantly, lower.

Finally, abnormally high urinary excretion of taurine has been reported in camptodactyly with mental deficiency (Nevin et al., 1969), in familial cerebellar dyssynergia (Hall et al., 1974), in myotonic dystrophy associated with generalized aminoaciduria (Blahd et al., 1955), and in Friedreich's ataxia (Lemieux et al., 1976). It is known that, in the rat, $37 \%$ of administered radioactive taurine is eliminated in the urine and $8.6 \%$ in the feces while the rest is usually retained and distributed in the organism, mainly muscles (Bouquet and Fromageot, 1965; Portman and Mann, 1955).

Our results (Fig. 1) show that twice as much of a load dose of taurine is excreted in the urine in Friedreich's ataxia as in control patients. Ataxics can thus not retain taurine as well as normal subjects. In the presence of a normal intestinal absorption, serum concentration, and uptake mechanisms of taurine previously demonstrated (Lemieux et al., 1976; Barbeau et al., 1976; Filla et al., 1978), such a result must be due either to an abnormal distribution in the organism or to an abnormality in renal excretion or reabsorption of the amino acid. Because of the important role of muscle for taurine reserves, a decreased size of the muscle pool would explain a decreased ability to retain taurine. The other explanation, of course, would implicate a defect in tubular reabsorption of taurine and $\beta$ alanine. A localized renal transport defect for these amino acids, which utilize the same transport system (Chesney et al., 1978), is still possible despite the lack of evidence for a generalized uptake defect for taurine (Filla et al., 1978). At the present time we favor the first hypothesis, a decreased muscle mass or reserve pool. Thus, in the presence of normal dietary intake of taurine, the Friedreich's ataxia patient would be in relative body deficiency of taurine, especially when metabolic stressful situations (such as tissue accumulation of calcium) require the presence of more taurine to immobilize or neutralize by binding this potentially cytotoxic action. The taurine loss thus appears to be an indirect consequence of subtle membrane anomalies in that disease, and possibly an important contributor to the cardiomyopathy (see elsewhere in this issue).

\section{ACKNOWLEDGEMENTS}

These studies were supported in part by l'Association Canadienne de l'Ataxie de Friedreich and by the United Parkinson Foundation. Thanks are due to Mrs. France Landreville and Miss Marie Charbonneau for technical assistance and to Miss Suzanne Gariépy for typing the manuscript.

\section{REFERENCES}

ANFANO, M. A., NAEWANIJ, J. O. and LAMB, A. I. (1978). Simplified two-step column chromatographic determination of taurine in urine. Clin. Chem. 24: 321-325.

BARBEAU, A., BRETON, G., LEMIEUX, B. and BUTTERWORTH, R. F. (1976). Bilirubin metabolism in Friedreich's ataxia Preliminary investigation. Can. J. Neurol. Sci. 3: 365-372.

BERTONI, J. M., FALLS, H. F., ALPERN, M., KORMEN, E., ABRAHAM, F. A. and BOSSEMEYER, R. W. (1978). Fat soluble vitamin deficiency syndrome resembling Bassen-Kornzweig disease. Neurology 28 : 390.

BLAHD, W. H., BLOOM, A. and DRELL, W. (1955). Qualitative study of aminoaciduria in muscular dystrophy and myotonia dystrophica. Proc. Soc. Exp. Biol. Med. 90: 704-706.

BOUQUET, P. L. and FROMAGEOT, $P$ (1965). Sur l'origine de la taurine urinaire excrétée par le rat soumis à une irradiation par le ${ }^{60} \mathrm{Co}$. Biochim. Biophys. Acta 3: 40-50.

CHESNEY, R. W., JAX, D. K., SCRIVER, C. R. and MOHYUDDIN, F. (1978). Taurine transport in mammalian kidney. In: Taurine and Neurological Disorders, ed. A. Barbeau and R. J. Huxtable, Raven Press, New York, pp. 73-93.

FILLA, A., BUTTER WORTH, R. F., GEOFFROY, G., LEMIEUX, B. and BARBEAU, A. (1978). Platelet taurine uptake in spinocerebellar degeneration. Can. J. Neurol. Sci. 5:125-130.
FREDRICKSON, O. S., GOTTO, A. M. and LEVY, R. I. (1972). Familial lipoprotein deficiency. In: The Metabolic Basis of Inherited Disease (J. B. Stanbury; J. B. Wyngaarden and D. S. Fredrickson, eds.), 3rd Edition, McGraw-Hill, New York, pp. 493-530.

HALL, C. D., STOWE, F. R. and SUMMER, G. K. (1974). Familial cerebellar dyssynergia and myoclonus epilepsy associated with defect of a mino acid metabolism. Neurology 24: 375.

HOWLAND, J. L. and IYER, J. L. (1977). Erythrocyte lipids in heterozygous carriers of Duchenne Muscular Dystrophy. Science 198: 309-311.

HUANG, Y. S., NESTRUCK, A. C., BARBEAU, A., BOUCHARD, J. P. and DAVIGNON, J. (1978). Plasma lipids and lipoproteins in Friedreich's ataxia and familial spastic ataxia - Evidence for an abnormal composition of high density lipoproteins. Can. J. Neurol. Sci. 5: 149-156.

KARLSSON, I., ALLING, C. and SVENNERHOLM, L. (1971). Major plasma lipids and their fatty acid composition in multiple sclerosis and other neurological diseases. Acta Neurol. Scand. 47: 403-412.

KUNZE, D., REICHMANN, G., EGGER, E., LEUSCHNER, G. and ECKHARDT, H. (1973). Erythrozytenlipide Bei Progressiver Muskeldystrophie. Clin. Chim. Acta, 43: 333-341.

LEMIEUX, B., BARBEAU, A., BERONIADE, V., SHAPCOTT, D., BRETON, G., GEOFFROY, G. and MELANCON, S. (1976). Amino acid metabolism in Friedreich's ataxia. Can. J. Neurol. Sci. 3: 373378.

MARCUS, A. J., SUFIER, L. B. and ULLMAN, H. L. (1972). The lipids of human platelets. In: Blood lipids, lipoproteins: quantitation, composition and metabolism. Ed. by G. J. Nelson, Wiley \& Sons Inc., New York, pp. 417-439.

MARS, H., LEWIS, L. A., LAZZARINIROBERTSON, A., BUTKUS, A. and WILLIAMS, G. H. (1969). Familial hypo- $\beta$ lipoproteinemia. Am. J. Med. 46: 886-900.

MARTINEK, R. G. (1964). Method for the determination of Vitamin $\mathrm{E}$ (total tocopherols) in serum. Clin. Chem. 10: 1078-1086.

McBRIDE, J. A. and JACOB, H. S. (1970). Abnormal kinetics of red cell membrane cholesterol in acanthocytes: studies in genetic and experimental abetalipoproteinemia and in spur cell anemia. Brit. J. Haemat. 18: 383-397.

NEVIN, N., HURWITZ, J. L. and NEILL, D. W. (1964). Camptodactyly with mental deficiency. J. Med. Genet. 3: 265-268.

PORTMAN, O. W. and MANN, G. V. (1955). The distribution of taurine-S $\mathrm{S}^{35}$ and taurocholates-S ${ }^{35}$ in the rat: dietary influences. J. Biol. Chem. 213: 733-743. 
ROSES, A. D. and APPEL, S. H. (1974). Muscular dystrophies. Lancet 2: 1400.
TAKAHASHI, Y., URUNO, K. and KIMURA, S. (1977). Vitamin E binding proteins in human serum. J. Nutr. Sci. Vitaminol. 23: 201-209.
TSEN, C. C. (1961). An improved spectrophotometric method for the determination of tocopherols using 4,7-diphenyl-1, 10-phenantroline. Anal. Chem. 33: 849-851. 